GRASAS Y ACEITES 69 (4)

October-December 2018, e275

ISSN-L: 0017-3495

https://doi.org/10.3989/gya.0112181

\title{
Physicochemical characteristics and oxidative stability of Egyptian corn germ oil produced by aqueous enzymatic extraction
}

\author{
A.Y. Esmat ${ }^{\mathrm{a}, \varpi}$, R.E. Hassan ${ }^{\mathrm{a}}$, G.A. Abo-ElWafa ${ }^{\mathrm{b}}$, M.M. Abou-ElSoud ${ }^{\mathrm{b}}$ and M.G. Megahed ${ }^{\mathrm{b}}$ \\ ${ }^{a}$ Department of Biochemistry, Faculty of Science, Ain Shams University, Cairo, Egypt \\ ${ }^{b}$ Department of Fats and Oils, National Research Centre, Cairo, Egypt \\ ${ }^{\square}$ Corresponding author: amryesmat@yahoo.com
}

Submitted: 23 January 2018; Accepted: 30 May 2018

SUMMARY: The physicochemical properties and the oxidative stability of Egyptian corn germ oil produced by aqueous enzymatic extraction using fungal cellulase, bacterial and bovine proteases, either individually or in combination were compared to that extracted by hexane. The optimized conditions of the new bovine protease for maximum oil yield were: $0.1 \%$ enzyme, $\mathrm{pH} 7.5$ and $1 \mathrm{~h}$ incubation time versus $0.6 \%, 0.63 \%$ enzyme, $\mathrm{pH} 4,8.2$ and $4,2 \mathrm{~h}$ incubation for fungal cellulase and bacterial protease, respectively. The higher oil yield was obtained by combining cellulase with bacterial protease $(62.38 \%)$ or with bovine protease $(51.94 \%)$ relative to hexane extraction (100\%). The refractive index, iodine, saponification and peroxide values, DPPH scavenging activity, as well as fatty acids composition of enzymes and solvent-extracted oils were comparable. The acid value and color index of the enzyme-extracted oils were better than that produced by hexane, indicating that enzymes could be applied in the production of eco-friendly corn oil.

KEYWORDS: Antioxidant and oxidative properties; Bacterial protease; Bovine protease; Corn germ oil; Fungal cellulase; Physicochemical properties

RESUMEN: Características fisicoquímicas y estabilidad oxidativa del aceite de germen de maíz egipcio producido por extracción enzimática acuosa. Las propiedades fisicoquímicas y la estabilidad oxidativa del aceite de germen de maíz egipcio producido por extracción enzimática acuosa utilizando celulasas fúngicas, proteasas bacterianas y bovinas, ya sea individualmente o en combinación, se compararon con las extraídas con hexano. Las condiciones óptimas de la nueva proteasa bovina para un rendimiento máximo de aceite fueron: $0,1 \%$ enzima, $\mathrm{pH} 7.5$ y tiempo de incubación $1 \mathrm{~h}$ versus $0,6 \%, 0,63 \%$ enzima, $\mathrm{pH} 4 ; 8,2$ y $4 ; 2 \mathrm{~h}$ de incubación para celulasa fúngica y proteasa bacteriana, respectivamente. El mayor rendimiento de aceite se obtuvo combinando celulasa con proteasa bacteriana $(62,38 \%)$ o con proteasa bovina $(51,94 \%)$ en relación con la extracción de hexano (100\%). El índice de refracción, yodo, saponificación y los valores de peróxido, la actividad de eliminación de DPPH, así como la composición de ácidos grasos de los aceites extraídos enzimáticamente y los extraídos con disolventes fueron comparables. El índice de acidez y el índice de color de los aceites extraídos con enzimas fueron mejores que los obtenidos con el hexano, lo que indica que las enzimas podrían aplicarse en la producción de aceite de maíz ecológico.

PALABRAS CLAVE: Aceite de germen de maiz; Celulasa fúngica; Propiedades antioxidantes y oxidativas; Propiedades fisicoquímicas; Proteasa bacteriana; Proteasa bovina

ORCID ID: Esmat AY https://orcid.org/0000-0002-6360-2354, Hassan RE https://orcid.org/0000-0002-5386-7092, Abo-Elwafa GA https://orcid.org/0000-0002-2681-6249, Abou-Elsoud MM https://orcid.org/0000-0002-6731-5424, Megahed MG https://orcid.org/0000-0001-8057-7034

Citation/Cómo citar este artículo: Esmat AY, Hassan RE, Abo-Elwafa GA, Abou-Elsoud MM, Megahed MG. 2018. Physicochemical characteristics and oxidative stability of Egyptian corn germ oil produced by aqueous enzymatic extraction. Grasas Aceites 69 (4), e275. https://doi.org/10.3989/gya.0112181

Copyright: (C2018 CSIC. This is an open-access article distributed under the terms of the Creative Commons Attribution 4.0 International (CC BY 4.0) License. 


\section{INTRODUCTION}

Due to global warming and the increasing danger of environmental pollution for human health, the world is seeking for greener technology in every sector of life. Also, there is a compelling increase in the demand for vegetable oils due to continuous expansion of the world population. Thus, the vegetable oil industry is facing a challenge to overcome the widening supply gap in the present demand.

Corn cereal grain (Zea mays L.) is one of the most important sources of vegetable oils. Its oil is commercially obtained from corn germ, which constitutes $5-14 \%$ of the weight of the kernel, and contains $18-41 \%$ oil (Johnston et al., 2005). Corn oil is rich in polyunsaturated fatty acids and has low saturated fatty acids, which has the advantages of being easy to digest, providing the heart with healthy fat, reducing the risk of chronic diseases, preventing macular degeneration and it is also good for hair treatment (Shende and Sidhu, 2014).

Since the extraction process affects the quality and quantity of the obtained oil, a proper extraction method should be chosen depending on the type and structure of the oil in order to obtain oil with good quality and maximum yield. Corn oil is industrially extracted from corn germ using n-hexane, which is a process that requires huge facilities with high capital and operating costs in order to maintain safety and environmental regulations (Moreau et al., 2009). Although solvent extraction using $\mathrm{n}$-hexane gives the maximum efficiency regarding oil yield, the produced oil can be with low quality due to further processing steps (refining, bleaching and deodorization) that require high temperatures. Also, the extracted oil may contain solvent residues which are considered to be a health hazard factor (Xie et al., 2011). Other oil extraction methods like mechanical pressing and the aqueous extraction method can be alternative methods for solvent extraction and considered to be environmentally friendly methods but with lower extracting efficiency (Balvardi et al., 2015).

The aqueous enzymatic extraction method is a solvent-free method and has a high specificity with low operating temperature and mild conditions leading to the production of high quality oil and protein (Xie et al., 2011; Mojtaba and Fardin, 2013). Moreover, the enzymatic pretreatment facilitates the oil release from the seeds through the degradation of seed cell wall components, which means a relatively higher oil yield. Moreau et al., (2004 and 2007) have demonstrated that the aqueous enzymatic oil extraction process achieves an oil yield of $80-90 \%$ using corn germ from a commercial corn wet mill. Also, Latif and Anwar (2009) reported that some enzyme preparations containing cellulases, hemicellulases, pectinases and proteases are quite effective in different vegetable oil extractions.
Bovine pancreatic protease type I is a crude mixture of serine endopeptidases including trypsin, chemotrypsin and other endopeptidases. It resembles Bacillus licheniformis protease (Alcalase 2.4L or Subtilisin A) in the presence of a serine group in its active catalytic site. Both enzymes have a common reaction mechanism consisting of a common catalytic triad of the three amino acids: serine (nucleophile), aspartate (electrophile) and histidine (base). The objective of our work was to study the effect of an aqueous enzymatic extraction on the yield, quality and stability of corn germ oil using bovine pancreatic protease type I as a new source of protease, as well as fungal cellulase from Trichoderma reesei and bacterial protease from Bacillus licheniformis, compared to the hexane extraction method. Also, the optimization of corn germ oil extraction using bovine pancreatic protease was carried out.

\section{MATERIALS AND METHODS}

\subsection{Materials}

Dry white corn germs (Zea mays L.) were obtained in plastic sacks from The National Company for Maize Products, $10^{\text {th }}$ of Ramadan city, Cairo, and stored at $-18{ }^{\circ} \mathrm{C}$. The corn germ samples were thawed at $4{ }^{\circ} \mathrm{C}$ the day before use. Fungal cellulase from Trichoderma reesei [ATCC 26921(C2730)] was obtained in an aqueous solution ( $\geq 700$ units/g) and stored at $4{ }^{\circ} \mathrm{C}$. Bacterial protease from Bacillus licheniformis (P 4860Alcalase $2.4 \mathrm{~L}$ or Subtilisin A) was obtained in an aqueous solution $(\geq 2.4 \mathrm{U} / \mathrm{g})$ and stored at $4{ }^{\circ} \mathrm{C}$. Protease from bovine pancreas Type I (P4630) was obtained in powder form ( $\geq 5$ units/ $\mathrm{mg}$ ) and stored at $-18{ }^{\circ} \mathrm{C}$. All enzymes were provided from Sigma-Aldrich corp. (USA), and all chemicals used were of pure analytical grade.

\subsection{Proximate analysis of corn germ}

The moisture and ash contents of corn germ were determined as described by Pearson (1976). The percentage of total protein was determined by the micro-kjeldahl method, and the percentage of total oil content was determined by extraction in n-hexane using the Soxhlet extraction system (AOAC, 2005). The percentage of total carbohydrate content was calculated by adding the mean values of the percentages of moisture, protein, lipid and ash and subtracting them from one hundred (Barminas et al., 1999).

\subsection{Hexane extraction method}

Corn germs were soaked in sufficient $n$-hexane and stirred for one hour at an ambient temperature $\left(25 \pm 3{ }^{\circ} \mathrm{C}\right)$ and then left overnight. The miscella (the mixture of corn germ oil and n-hexane) was 
collected and filtered. This step was repeated three times. The combined miscella was filtered through a small amount of anhydrous sodium sulfate using Whatman filter paper No.1 and then the filtrate was distilled under vacuum using a rotary evaporator at about $40{ }^{\circ} \mathrm{C}$. The obtained oil was then poured in dark brown glass bottles and kept at $-18^{\circ} \mathrm{C}$ until analysis (Moral and Méndez, 2006).

\subsection{Sample preparation for aqueous and enzymatic extractions}

Dry corn germs were treated in a microwave oven (SAMSUNG model M 9245, Korea), with a 2450 $\mathrm{MHz}$ microwave frequency and an output power of $1000 \mathrm{~W}$ for $20 \mathrm{sec}(\times 2)$ and stirred in between treatments, then gently ground in a blender (Moreau et al., 2009).

\subsection{Aqueous extraction method}

The aqueous extraction of corn germ oil was carried out without enzymes according to the method of Moreau et al., (2004) (scheme 1).

\subsection{Optimization of corn germ oil extraction by bovine pancreatic protease}

For optimizing corn germ oil extraction by bovine pancreatic protease, the extraction process was carried out on a small scale according to the method of Moreau et al., (2009) with slight modifications, using different concentrations of bovine pancreatic protease $(0.05,0.1,0.5,0.7,1 \mathrm{~g} / 100 \mathrm{~g}$ seeds), different seed concentrations $(5,10,15,25,30 \%)$ at different $\mathrm{pH}$ levels $(5,6,7.5,9,10)$ and for different incubation times $(30,45,60,90,120 \mathrm{~min}$ ), (Scheme 2). In each optimization experiment, only one factor was varied, while the others were kept fixed.

\subsection{Aqueous extraction of corn germ oil using different enzymes}

The extraction of corn germ oil was carried out in triplicate using fungal cellulase, bacterial protease and bovine pancreatic protease, either individually or in combination, under the optimized conditions for each enzyme (Scheme 3). The optimized conditions for fungal cellulase and bacterial protease were previously reported (Moreau et al., 2009), while those of pancreatic protease were obtained from the optimization experiments mentioned above.

\subsection{Physicochemical characterization of the extracted corn germ oil}

The color index of corn germ oil samples was calculated by the sum of sixteen absorbance values for the oil over the wave length range of 400-550 nm
(10 nm difference) multiplied by ten (Pons et al., 1960). The refractive index (RI) of the oil samples was determined at $20{ }^{\circ} \mathrm{C}$ using a refractometer (Rudolph model J157, Germany). Iodine, acid and saponification values for the oil samples were determined as previously described in AOCS Cd 1-25, Cd 3a-63 and Cd 3-25 respectively (2005).

\subsection{Analysis of fatty acid composition}

Fatty acids methyl esters were prepared using Boron trifluoride $\left(\mathrm{BF}_{3}\right)$ methanol reagent according to Wirasnita et al., (2013), then analyzed with a varian CP-3380 gas chromatography (GC) equipped with flame ionization detector. Fatty acids were

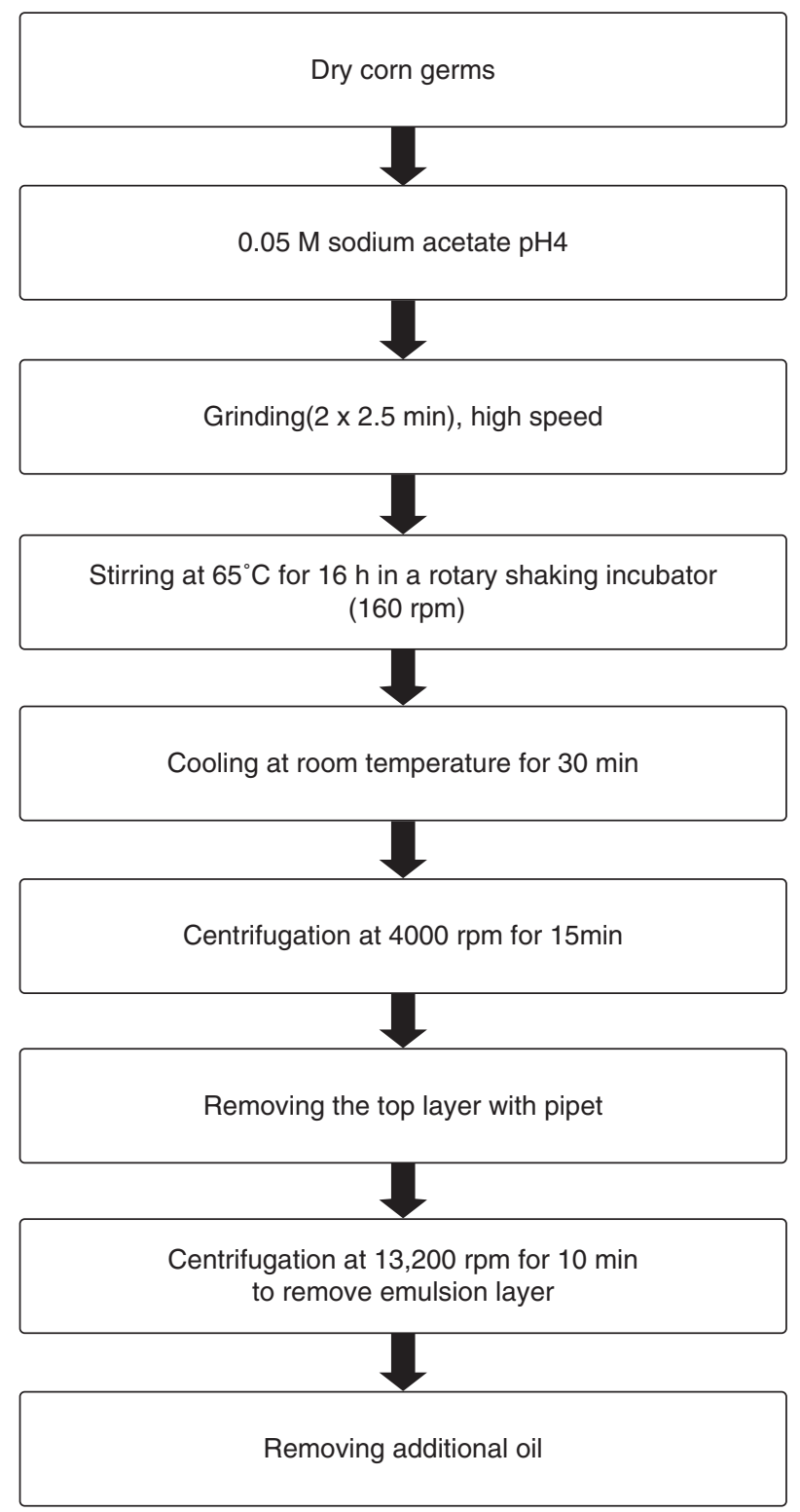

SCHEME 1. Steps of aqueous extraction of corn germ oil. 


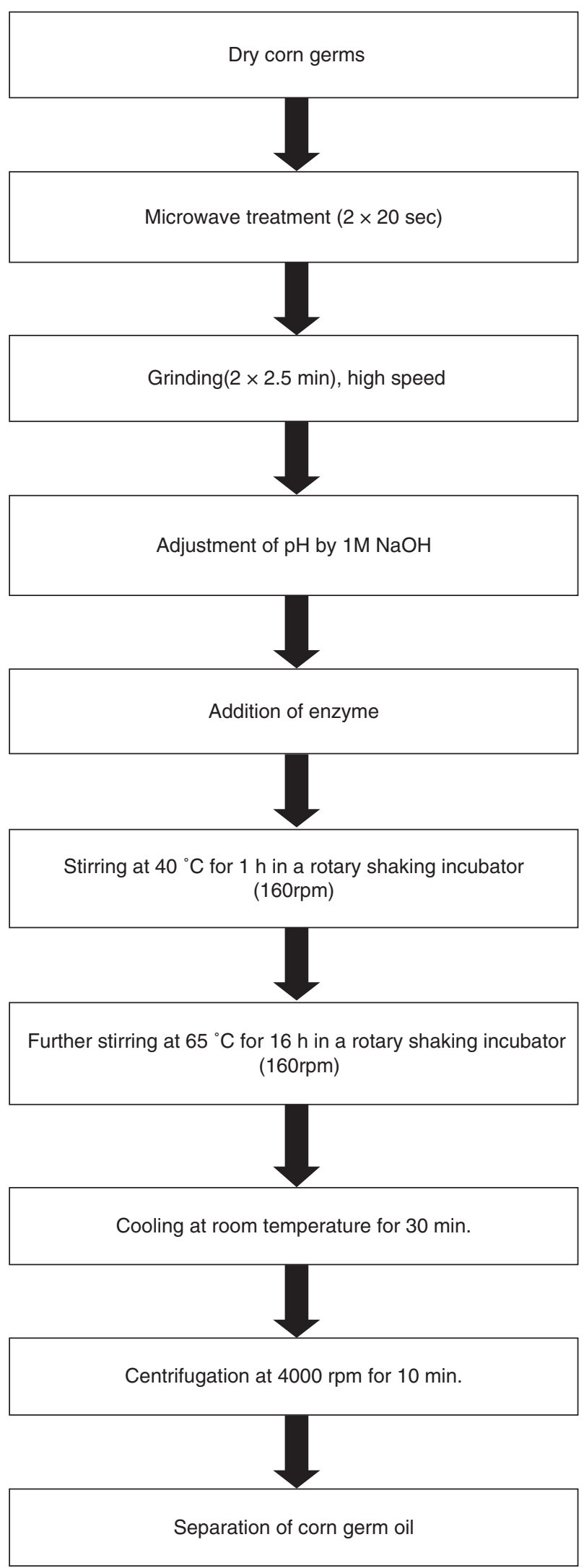

SCHEME 2. Steps of corn germ oil extraction by protease from bovine pancreas. separated using a Thermo-TR-FAMe column $(30 \mathrm{~m}$ in length $\mathrm{x} 0.25 \mathrm{~mm}$ i.d. $\mathrm{x} 0.25 \mu \mathrm{m}$ film thickness). The oven temperature was programmed in two stages as follows: first, the column temperature was increased to $40{ }^{\circ} \mathrm{C}$, held at $40{ }^{\circ} \mathrm{C}$ for $5 \mathrm{~min}$; then from 40 to $220^{\circ} \mathrm{C}$ at a rate of $3{ }^{\circ} \mathrm{C} / \mathrm{min}$. Detector and injector temperatures were kept at 250 and $230{ }^{\circ} \mathrm{C}$, respectively. The carrier gas (helium) flow rate was $1 \mathrm{ml} / \mathrm{min}$

\subsection{Total tocopherol concentration}

The tocopherol concentration of the oil samples was determined by a high performance liquid chromatography (HPLC) system (Shimadzu Prominence, Japan) as previously described (Turan et al., 2007). The normal phase column in the system was Inertsil $\mathrm{NH}_{2}$ column $(250 \mathrm{~mm}$ x $4.6 \mathrm{~mm}, 5$ $\mu \mathrm{m})$ and the column temperature was maintained at $30{ }^{\circ} \mathrm{C}$. Separation of tocopherols was based on isocratic elution with n-hexane (96\%) and isopropanol $(4 \%)$ at $1 \mathrm{ml} / \mathrm{min}$. The elute was monitored at $292 \mathrm{~nm}$ using a photodiode-array detector (SPD-M20A). The compounds were identified by comparing their retention times and the UV spectra with a standard mixture of $\alpha$-, $\beta$-, $\gamma$ - and $\delta$-tochopherols (W530066) obtained from the Sigma Aldrich comp. (USA). Tocopherol was quantified based on the peak areas compared with those of the standard mixture and the total tochopherol concentration was then calculated by summation of the separated $\alpha,-\beta-, \gamma-, \delta-$ tocopherol fractions.

\subsection{Antioxidant test}

The radical scavenging power of the oil samples was estimated by the 2,2'diphenyl-1-picrylhydrazyl (DPPH) method as described by Blois (1958). Briefly, $50 \mu \mathrm{l}$ of oil sample were added to $1 \mathrm{ml}$ of pure methanol and $2 \mathrm{ml}$ of freshly prepared DPPH solution (in $0.13 \mathrm{mM}$ methanol). The sample solution was vigorously shaken in a vortex for $30 \mathrm{sec}$, then placed in a spectrophotometer (T80 UV/VIS Spectrometer, PG Instruments Ltd, UK), and the absorbance was measured at $532 \mathrm{~nm}$ against pure methanol after exactly 30 min. A blank was made exactly as above except for replacing the oil sample with $50 \mu \mathrm{l}$ pure methanol. Percentage of radical scavenging activity (RSA \%) was calculated from the following equation:

RSA $\%=$ (absorbance of blank - absorbance of sample / absorbance of blank) $\times 100$

The minimum effective concentration of oil sample required to scavenge DPPH radical by $50 \%$ (IC50 value) was obtained by linear regression analysis of a dose-response curve plotted between 
Physicochemical characteristics and oxidative stability of Egyptian corn germ oil produced by aqueous enzymatic extraction $\bullet 5$

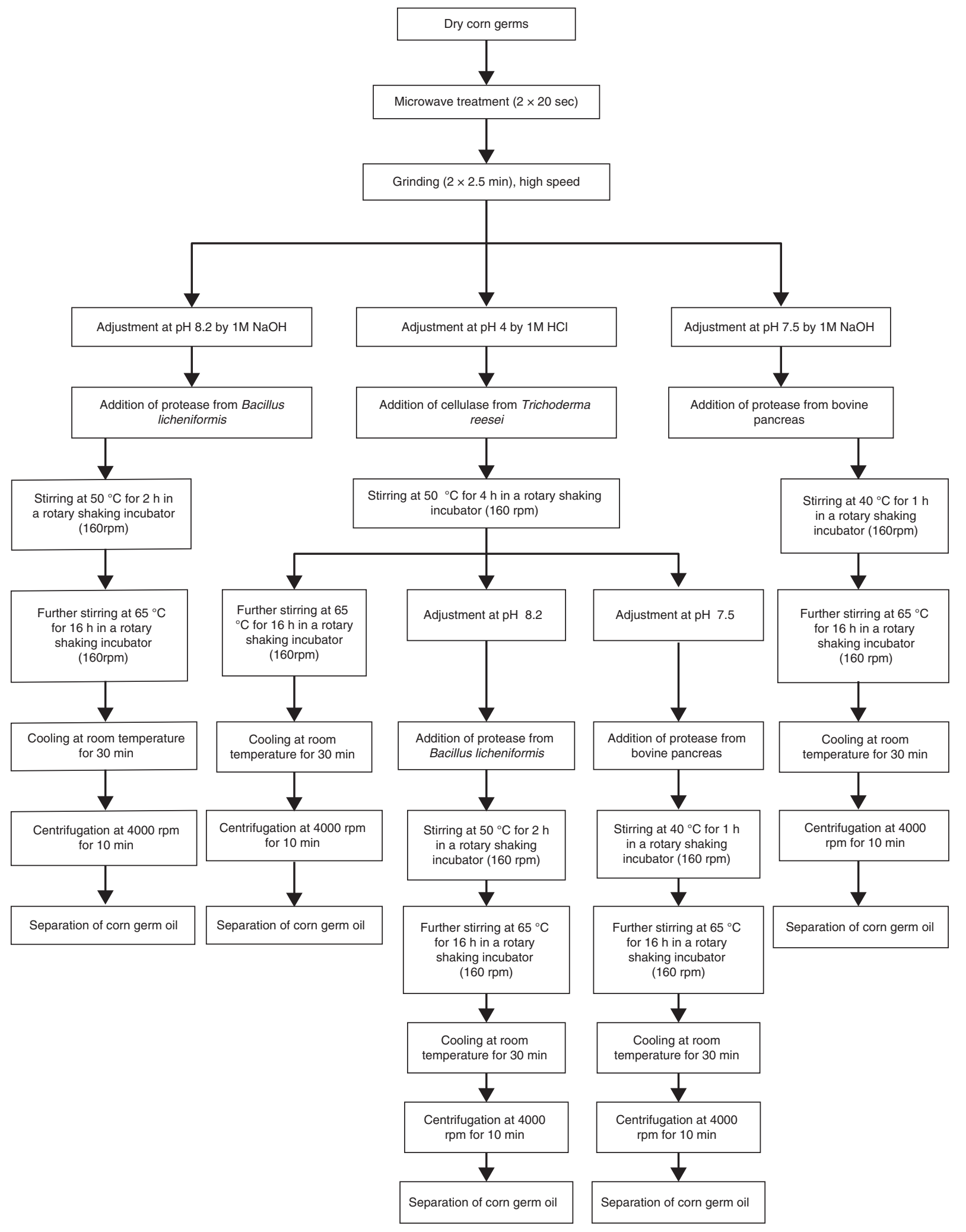

SCHEME 3. Steps of aqueous enzymatic extraction of corn germ oil using fungal cellulase, bacterial protease and /or pancreatic protease. 
RSA \% and different concentrations of each oil sample $(40-200 \mu \mathrm{g} / \mathrm{ml})$.

\subsection{Oxidative stability tests}

The peroxide value of the oil samples was performed according to AOCS, Cd 8-53 (2005). The induction period of fat is defined as the lag period during which a fat or oil shows stability to oxidation because of its content of antioxidants, natural or added, which are oxidized preferentially. After this there is a sudden consumption of oxygen and the fat becomes rancid (Bender, 2009). The induction period of the oil samples was determined according to Kowalski et al., (2004) by the Metrohm Rancimat apparatus model 743 (Metrohm, Switzerland). A weight of $5 \mathrm{~g}$ oil sample was placed in the reaction vessel glassware. The conductimetry cells were filled with deionized water up to $60 \mathrm{ml}$. Samples were heated at $110{ }^{\circ} \mathrm{C}$ and air was passed through the heated oil at a rate of $20 \mathrm{~L} / \mathrm{h}$. The induction period was determined automatically by the device at $110^{\circ} \mathrm{C}$ in hours.

\subsection{Statistical analysis}

The data obtained in this work were presented as the mean \pm standard deviation of three replicate experiments. Statistical analysis of the data was carried out by single factor analysis of variance (ANOVA) using SPSS 20.0 software (2011) (Chicago, IL, USA). Statistically significant differences between means were determined by Duncan's multiple range test at $\mathrm{p}<0.05$.

\section{RESULTS}

\subsection{Proximate analysis of white corn germ}

Table (1) shows the chemical composition of white corn germs where the percentage of total oil, total carbohydrates, total protein, moisture and ash contents were found to be $43.83,41.76,11.45,1.87$ and $1.09 \%$, respectively.

TABLE 1. Chemical composition of white corn germs

\begin{tabular}{lc}
\hline Components & Concentration (g/100g corn germ) \\
\hline Oil & $43.83 \pm 2.16$ \\
Carbohydrate & $41.76 \pm 0.25$ \\
Protein & $11.45 \pm 0.44$ \\
Moisture & $1.87 \pm 0.04$ \\
Ash & $1.09 \pm 0.01$ \\
\hline
\end{tabular}

Results are expressed as means \pm SD of triplicate experiments. Analyzed by ANOVA using SPSS 20.0 software. Statistically significant differences among means were determined by Duncan's multiple range test at $\mathrm{p}<0.05$.

\subsection{Optimization of corn germ extraction by bovine pancreatic protease}

\subsubsection{Effect of bovine pancreatic protease concentration on corn germ oil yield}

The optimum concentration of bovine pancreatic protease on the oil yield was determined by using different enzyme concentrations $(0.05,0.1,0.5,0.7$ and $1 \mathrm{~g}$ enzyme $/ 100 \mathrm{~g}$ seeds). The highest yield of corn germ oil was obtained at the enzyme concentration $(0.1 \%)$, while the lowest oil yield was produced at the enzyme concentration (0.05\%), (Figure 1).

\subsubsection{Effect of corn germ concentration on oil yield}

The optimum effect of corn germ concentration on oil yield was assessed using different concentrations of corn germ $(5,10,15,25$ and $30 \%)$ which are equivalent to $(1: 20,1: 10,1: 6.7,1: 4$ and 1:3) of germ to water ratio $(\mathrm{w} / \mathrm{v})$, respectively. A gradual increase in the oil yield was recorded by increasing germ concentration up to $20 \%$, at which a maximum oil yield of $6.43 \%$ was obtained. However, a sharp decline in the oil yield $(2.18 \%)$ was produced at a $30 \%$ concentration. Since both concentrations of corn germ (15 and $25 \%$ ) produced more or less the same oil yield (6.02 and 6.43\%, respectively) (Figure 2). Thus, 15\% was chosen as the optimum corn germ concentration for extraction by pancreatic protease to economize substrate consumption.

\subsubsection{Effect of $p H$ on corn germ oil yield}

Figure 3 shows the effect of different $\mathrm{pH}$ values $(5,6,7.5,9$ and 10) on corn germ oil extraction by pancreatic protease. The oil yield was found to increase as the $\mathrm{pH}$ value increased up to $\mathrm{pH} 7.5$, at which the oil yield was at its maximum (6.02\%), followed by a sharp decrease in the oil yield reaching 2.78 and $2.24 \%$ at $\mathrm{pH} 9$ and 10 , respectively.

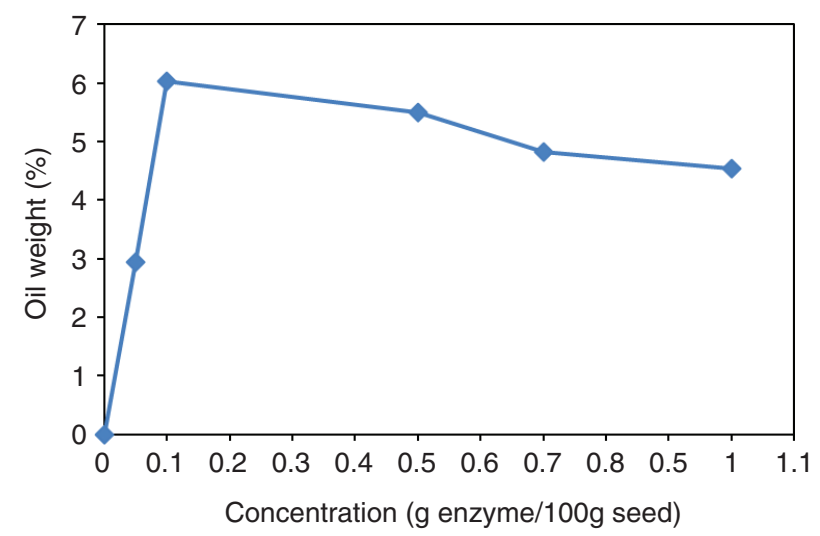

FIGURE 1. Effect of bovine pancreatic protease concentration on corn germ oil weight (expressed as percentage). 


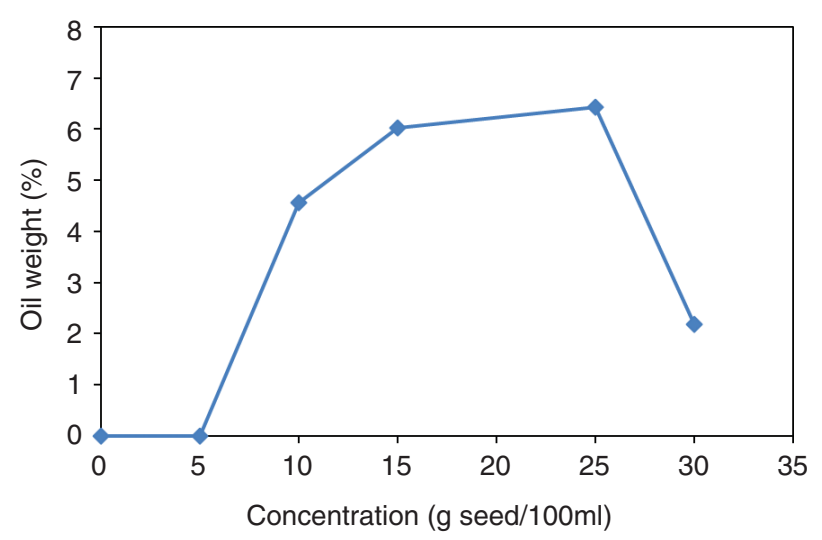

FIGURE 2. Effect of corn germ concentration on oil weight (expressed as percentage) using bovine pancreatic protease.

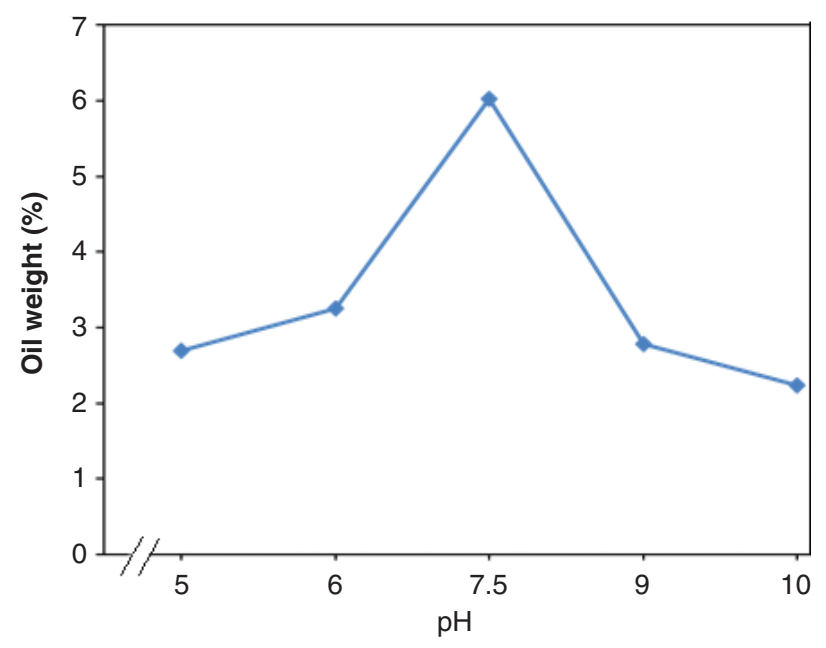

FIGURE 3. Effect of pH on corn germ oil weight (expressed as percentage) using bovine pancreatic protease.

\subsubsection{Effect of different incubation times on corn germ oil yield}

Figure 4 depicts the effect of different incubation periods $(30,45,60,90$ and $120 \mathrm{~min}$.) on the enzymatic extraction of corn germ oil. It was observed that the oil yield was at its maximum at the incubation time of $60 \mathrm{~min}$ and at its minimum at $120 \mathrm{~min}$. Taken altogether, the optimum conditions for the extraction of corn germ oil using bovine pancreatic protease were $0.1 \%$ enzyme concentration, $15 \%$ corn germ concentration, pH 7.5 and incubation time of $60 \mathrm{~min}$.

\subsection{Effect of enzyme type on oil extraction yield}

Table 2 presents the absolute oil weights obtained by aqueous and aqueous enzymatic methods and their relative weights with respect to the hexane method $(100 \%)$. The aqueous extraction of corn germ oil produced an oil yield of $8.71 \%$ relative to that of hexane extraction. Applying the different enzymes individually

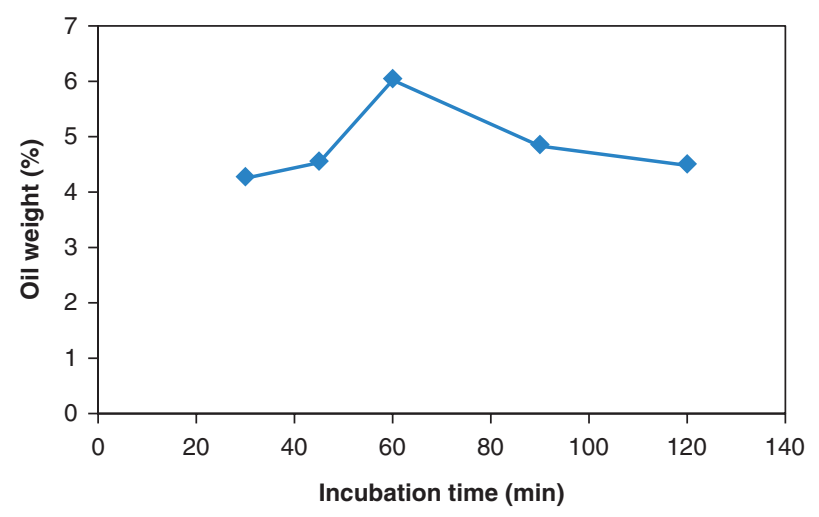

FIGURE 4. Effect of incubation time on corn germ oil weight (expressed as percentage) using bovine pancreatic protease.

TABLE 2. Absolute and relative weights of corn germ oil extracted by hexane and different enzymes

\begin{tabular}{lcc}
\hline Oil extracted by & $\begin{array}{c}\text { Absolute weight } \\
\text { (g oil/100 g germ) }\end{array}$ & $\begin{array}{c}\text { Relative } \\
\text { weight (\%) }\end{array}$ \\
\hline Hexane $^{2}$ & $43.83 \pm 2.16^{\mathrm{a}}$ & $100^{\mathrm{a}}$ \\
Aqueous & $3.82 \pm 0.03^{\mathrm{b}}$ & $8.71 \pm 0.06^{\mathrm{b}}$ \\
Enzyme 1 & $16.50 \pm 1.79^{\mathrm{c}}$ & $37.65 \pm 4.09^{\mathrm{c}}$ \\
Enzyme 2 & $4.44 \pm 0.30^{\mathrm{b}}$ & $10.14 \pm 0.68^{\mathrm{b}}$ \\
Enzyme 3 & $5.97 \pm 0.32^{\mathrm{b}}$ & $13.62 \pm 0.72^{\mathrm{b}}$ \\
Enzyme 1 + Enzyme 2 & $27.34 \pm 0.71^{\mathrm{d}}$ & $62.38 \pm 1.62^{\mathrm{d}}$ \\
Enzyme 1+ Enzyme 3 & $22.76 \pm 1.51^{\mathrm{d}}$ & $51.94 \pm 3.45^{\mathrm{d}}$ \\
\hline
\end{tabular}

Enzyme 1: cellulase from Trichoderma reesei

Enzyme 2: protease from Bacillus licheniformis

Enzyme 3: protease from bovine pancreas

${ }^{1}$ Relative oil yield $=\%$ oil extracted by an enzyme $/ \%$ oil extracted by hexane $\times 100$

${ }^{2}$ Hexane-extracted oil by the Soxhlet method (\%) equivalent to total oil content Results are expressed as means \pm SD of triplicate experiments. Data was statistically analyzed by ANOVA using SPSS 20.0 software. Statistically significant differences among means were determined by Duncan's multiple range test at $p<0.05$. Different symbols indicate significantly different at $p<0.05$

showed that cellulase produced the highest relative oil yield of $37.65 \%$ followed by bovine pancreatic protease with $(13.62 \%)$ and protease from Bacillus licheniformis $(10.14 \%)$. On the other hand, the combination of cellulase and protease from Bacillus licheniformis showed a significant increase in oil yield $(62.38 \%)$ relative to hexane extraction, and compared to aqueous extraction and to the other enzymes. Also, combining cellulase and bovine pancreatic protease produced a significant but less pronounced increase in the relative corn germ oil yield (51.94\%), compared to the aqueous method and individual enzymes.

\subsection{Effect of aqueous enzymatic extraction on the physical and chemical characteristics of the extracted oil samples}

Table 3 shows a significant decrease in the color index $(\mathrm{p}<0.05)$ of the corn germ oil extracted by 
TABLE 3. Physicochemical characteristics of corn germ oil extracted by hexane and different enzymes

\begin{tabular}{lccccc}
\hline Oil extracted by & Color index & Refractive index & $\begin{array}{c}\text { Acid value } \\
(\mathbf{m g ~ K O H / g})\end{array}$ & $\begin{array}{c}\text { Iodine value } \\
(\mathbf{g} / \mathbf{1 0 0 g})\end{array}$ & $\begin{array}{c}\text { Saponification } \\
\text { value }(\mathbf{m g} / \mathbf{g})\end{array}$ \\
\hline Hexane & $215.91 \pm 0.85^{\mathrm{a}}$ & $1.4635 \pm 0.0002^{\mathrm{a}}$ & $5.60 \pm 0.13^{\mathrm{a}}$ & $107.63 \pm 0.91^{\mathrm{a}}$ & $197.89 \pm 19.46^{\mathrm{a}}$ \\
Enzyme 1 & $214.57 \pm 0.42^{\mathrm{a}}$ & $1.4635 \pm 0.0003^{\mathrm{a}}$ & $5.36 \pm 0.03^{\mathrm{b}}$ & $104.82 \pm 3.22^{\mathrm{a}}$ & $169.55 \pm 8.89^{\mathrm{a}}$ \\
Enzyme 2 & $178.5 \pm 0.71^{\mathrm{b}}$ & $1.4640 \pm 0.0002^{\mathrm{a}}$ & $4.86 \pm 0.02^{\mathrm{c}}$ & $107.09 \pm 2.93^{\mathrm{a}}$ & $188.05 \pm 18.90^{\mathrm{a}, \mathrm{b}}$ \\
Enzyme 3 & $186.72 \pm 0.40^{\mathrm{c}}$ & $1.4640 \pm 0.0004^{\mathrm{a}}$ & $2.78 \pm 0.08^{\mathrm{d}}$ & $108.34 \pm 0.79^{\mathrm{a}}$ & $217.66 \pm 10.13^{\mathrm{a}, \mathrm{b}, \mathrm{c}}$ \\
Enzyme 1+ Enzyme 2 & $193.4 \pm 0.42^{\mathrm{d}}$ & $1.4640 \pm 0.0004^{\mathrm{a}}$ & $4.99 \pm 0.12^{\mathrm{c}}$ & $111.80 \pm 7.48^{\mathrm{a}}$ & $237.35 \pm 22.91^{\mathrm{a}, \mathrm{c}}$ \\
Enzyme 1+ Enzyme 3 & $177.06 \pm 0.57^{\mathrm{e}}$ & $1.4640 \pm 0.0002^{\mathrm{a}}$ & $5.20 \pm 0.02^{\mathrm{b}}$ & $103.88 \pm 0.11^{\mathrm{a}}$ & $220.33 \pm 6.95^{\mathrm{a}, \mathrm{b}, \mathrm{c}}$ \\
\hline
\end{tabular}

Enzyme 1: cellulase from Trichoderma reesei

Enzyme 2: protease from Bacillus licheniformis

Enzyme 3: protease from bovine pancreas

Results are expressed as means \pm SD of triplicate experiments. Data was statistically analyzed by ANOVA using SPSS 20.0 software. Statistically significant differences among means were determined by Duncan's multiple range test at $p<0.05$. Different symbols indicate significantly different at $\mathrm{p}<0.05$

TABLE 4. Fatty acid composition of corn germ oil extracted by hexane and different enzymes

\begin{tabular}{lcccccc}
\hline & \multicolumn{5}{c}{ Extraction method } \\
\cline { 2 - 7 } Fatty Acid (\%) & Hexane & Enzyme 1 & Enzyme 2 & Enzyme 3 & Enzyme 1 + Enzyme 2 & Enzyme 1+ Enzyme 3 \\
\hline Myristic C14:0) & 0.01 & 0.02 & 0.01 & 0.25 & 0.01 & 0.01 \\
Palmitic (C16:0) & 10.34 & 11.38 & 9.80 & 11.47 & 10.44 & 10.67 \\
Palmitoleic (C16:1) & 0.13 & 0.11 & 0.10 & 0.01 & 0.13 & 0.10 \\
Heptadecanoic (C17:0) & 0.09 & 0.02 & 0.09 & 0.01 & 0.09 & 0.09 \\
Heptadecenoic (C17:1) & 0.05 & 0.16 & 0.19 & 0.35 & 0.16 & 0.19 \\
Stearic (C18:0) & 2.33 & 2.07 & 2.26 & 2.04 & 2.32 & 3.21 \\
Oleic (C18:1) & 33.00 & 32.64 & 32.79 & 33.27 & 32.24 & 52.30 \\
Linoleic (C18:2) & 52.55 & 51.64 & 53.11 & 51.05 & 52.88 & 0.99 \\
$\alpha$-Linolenic (C18:3) & 0.95 & 1.07 & 1.04 & 0.99 & 1.11 & 0.52 \\
Arachidic (C20:0) & 0.53 & 0.02 & 0.61 & 0.54 & 0.62 & 0.01 \\
Eicosenoic (C20:1) & 0.01 & 0.87 & 0.01 & 0.01 & 0.01 & 86.50 \\
TUSFA & 86.69 & 86.50 & 87.23 & 85.70 & 86.52 & 13.50 \\
TSFA & 13.30 & 13.50 & 12.77 & 14.31 & 6.49 & 6.41 \\
TUSFA/ TSFA & 6.52 & 6.41 & 6.83 & 5.99 & 6.42 & \\
\hline
\end{tabular}

Enzyme 1: cellulase from Trichoderma reesei

Enzyme 2: protease from Bacillus licheniformis

Enzyme 3: protease from bovine pancreas

TUSFA: Total unsaturated fatty acids

TSFA: Total saturated fatty acids

the different enzymes, compared to hexane extraction, except for cellulase-extracted oil. The lowest color index was recorded for the oil sample extracted by combined cellulase and pancreatic protease. On the other hand, non-significant differences were observed in the values of the refractive index, iodine and saponification of all the oil samples, compared to solvent extraction. The acid values for the oil samples using the different enzymes were significantly lower $(p<0.05)$ than that of the hexane extracted-oil, where the lowest acid value $(2.78 \mathrm{mgKOH} / \mathrm{g}$ oil) was recorded for the oil sample obtained by pancreatic protease under the implemented conditions.

\subsection{Effect of aqueous enzymatic extraction on the fatty acid composition of extracted oil samples}

Table 4 shows the analysis of the fatty acids composition in the corn germ oil extracted by hexane and different enzymes. Corn germ oil extracted either by hexane or different enzymes showed more or less equal amounts of total unsaturated fatty acids $(85.70-87.23 \%)$ and total saturated fatty acids (12.77-14.31\%). The ratio of total unsaturated fatty acids to total saturated fatty acids in all the oil samples was found to be comparable (5.99-6.83\%). Of the unsaturated fatty acids, linoleic acid (C18:2) ( $\omega-6)$ was found 
to be the major fatty acid in all the oil samples, whereas oleic acid $(\mathrm{C} 18: 1)(\omega-9)$ was intermediate and $\alpha$-linolenic acid (C18:3) ( $\omega$-3) and eicosenoic acid (C20:1) were minor. In general, the fatty acids composition of corn germ oil samples extracted either by solvent or aqueous enzymatic methods manifested no sharp variations.

\subsection{Effect of aqueous enzymatic extraction on the oxidative stability and induction period of the extracted oil samples}

Table 5 shows that of all the enzyme systems used in this study, bovine pancreatic protease significantly increased the total tocopherol content $(431 \mu \mathrm{g} / \mathrm{ml})$ in the corn germ oil, compared to hexane-extracted oil $(423 \mu \mathrm{g} / \mathrm{ml})$. In addition, corn germ oil produced by extraction with bacterial protease and by combining cellulase with bacterial protease or bovine protease showed reduced total tocopherol contents (390, 415 and $370 \mu \mathrm{g} / \mathrm{ml}$, respectively), compared to the hexane-extracted oil. The lowest peroxide value was recorded for oil samples extracted by cellulase and bovine pancreatic protease, (1.78 and $2.07 \mathrm{mEq} / \mathrm{kg}$ oil, respectively), compared to hexane-extracted oil $(3.14 \mathrm{mEq} / \mathrm{kg}$ oil). All the enzyme-extracted oil samples showed non-significant changes in their ability to scavenge DPPH radicals except for that extracted by combined cellulase and bovine pancreatic protease, which showed a significant increase in DPPH scavenging activity $\left(\mathrm{IC}_{50}\right.$ value $\left.10.9 \mathrm{mg} / \mathrm{ml}\right)$, compared to hexane-extracted oil $\left(\mathrm{IC}_{50}\right.$ value $\left.12.3 \mathrm{mg} / \mathrm{ml}\right)$. The induction periods of the corn germ oil samples extracted by the different enzymes either individually or combined were significantly reduced compared to hexane extraction. The lowest induction period was recorded for oils extracted by bacterial and bovine proteases (5.57 and 5.67h, respectively), whereas the highest induction period was for the oil extracted by fungal cellulase $(7.72 \mathrm{~h})$.

\section{DISCUSSION}

Recently, aqueous enzymatic extraction has emerged in the edible oil industry as a novel and an effective method for improving oil yield and quality, and for reducing the health and environmental risks associated with solvent extraction. To the best of our knowledge, this study is the first of its kind to adopt aqueous enzymatic extraction for the production of oil from Egyptian white corn germs. For comparison, solvent and aqueous extractions of corn germ oil were done in parallel. The chemical analysis of white corn germs shows its content of total oil $(43.83 \%)$, total carbohydrates $(41.76 \%)$, total protein $(11.45 \%)$, moisture $(1.87 \%)$ and ash (1.09\%) (Table1).

In this study, three enzymes were used; fungal cellulase from Trichoderma reesei, bacterial protease from Bacillus licheniformis and animal protease from bovine pancreas (Type I), either individually or in combination. Bovine pancreatic protease is used for the first time as a new source for protease, thus preliminary optimization experiments are necessary to attain the optimum conditions required for maximum oil extraction. The optimum conditions for bovine pancreatic protease action are $0.1 \%$ enzyme concentration, $15 \%$ corn germ concentration, $\mathrm{pH} 7.5$ and incubation time of $60 \mathrm{~min}$ (Figures 1-4). On the other hand, the implemented optimum conditions for fungal cellulase and bacterial protease actions were previously reported as: $0.6 \%$ and $0.63 \%$ enzyme concentration, $15 \%$ germ concentration, $\mathrm{pH} 4$ and 8 and incubation time of 4 and $2 \mathrm{~h}$, respectively (Moreau et al., 2009). It is worth noting that 0.1 $\%$ ( $\geq 500$ units) of bovine protease was required to obtain the maximum oil yield, compared to $0.63 \%$ ( $\geq 555$ units) of protease from Bacillus licheniformis. This confirms that although both enzymes are serine endopeptidases and have the same geometric orientations of the three active amino acid

TABLE 5. Tocopherol concentration, antioxidant and oxidative stability tests of corn germ oil extracted by hexane and different enzymes

\begin{tabular}{lcccc}
\hline Oil extracted by & $\begin{array}{c}\text { Total tocopherols } \\
(\boldsymbol{\mu} / \mathbf{m l})\end{array}$ & $\begin{array}{c}\text { DPPH scavenging } \\
\text { activity }\left(\mathbf{I C}_{\mathbf{5 0}}\right)(\mathbf{m g} / \mathbf{m l})\end{array}$ & $\begin{array}{c}\text { Peroxide value } \\
(\mathbf{m E q} / \mathbf{k g ~ o i l})\end{array}$ & $\begin{array}{c}\text { Induction time/h } \\
(\mathbf{a t} 110\end{array}$ \\
\hline Hexane & $\left.423 \pm 1.13^{\mathrm{a}}\right)$ & $12.3 \pm 0.71^{\mathrm{a}}$ & $3.14 \pm 0.35^{\mathrm{a}}$ & $14.76 \pm 0.42^{\mathrm{a}}$ \\
Enzyme 1 & $425 \pm 2.26^{\mathrm{a}}$ & $12.1 \pm 0.28^{\mathrm{a}}$ & $1.78 \pm 0.08^{\mathrm{b}}$ & $7.72 \pm 0.49^{\mathrm{b}}$ \\
Enzyme 2 & $390 \pm 1.41^{\mathrm{b}}$ & $11.5 \pm 0.14^{\mathrm{a}}$ & $2.79 \pm 0.04^{\mathrm{a}}$ & $5.57 \pm 0.21^{\mathrm{c}}$ \\
Enzyme 3 & $431 \pm 2.97^{\mathrm{c}}$ & $12.2 \pm 0.71^{\mathrm{a}}$ & $2.07 \pm 0.03^{\mathrm{b}}$ & $5.67 \pm 0.25^{\mathrm{c}}$ \\
Enzyme 1+ Enzyme 2 & $415 \pm 1.56^{\mathrm{d}}$ & $12.2 \pm 0.42^{\mathrm{a}}$ & $2.70 \pm 0.40^{\mathrm{a}}$ & $6.70 \pm 0.14^{\mathrm{d}}$ \\
Enzyme 1+ Enzyme 3 & $370 \pm 2.83^{\mathrm{e}}$ & $10.9 \pm 0.35^{\mathrm{b}}$ & $2.85 \pm 0.11^{\mathrm{a}}$ & $6.16 \pm 0.35^{\mathrm{e}}$ \\
\hline
\end{tabular}

Enzyme 1: cellulase from Trichoderma reesei

Enzyme 2: protease from Bacillus licheniformis

Enzyme 3: protease from bovine pancreas

Results are expressed as means \pm SD of triplicate experiments. Data was statistically analyzed by ANOVA using SPSS 20.0 software. Statistically significant differences among means were determined by Duncan's multiple range test at $\mathrm{p}<0.05$.

Different symbols indicate significantly different at $\mathrm{p}<0.05$ 
residues, their protein folds are quite different and provide a typical example of a convergent evolution (Rao et al., 1998).

In this study, a microwave pre-treatment of the dry corn germs was done prior to the extraction processes in order to enhance oil recovery. Moreau et al., (2009) reported that the microwave pretreatment of corn germs destroys the lipid body membrane and causes the oil in the lipid bodies to coalesce, which results in an enhancement in oil liberation. Comparing the oil yield obtained by aqueous extraction to that obtained by hexane extraction revealed that the former method gave rise to a very low oil yield $(8.71 \%)$ under the implemented extraction conditions (Table 2). On the other hand, enzymatic extraction using different enzymes revealed that cellulase produced a more pronounced increase in the relative oil yield (37.65\%), compared to the other enzymes; while the proteases produced nonsignificant variations in the relative oil yield (10.14, $13.62 \%$ respectively), compared to aqueous extraction (Table 2). Moreau et al., (2004) have demonstrated that unlike most oil seeds, corn germs contain arabinoxylans as the most abundant carbohydrate polymer, which means that the enzyme preparations containing cellulase activities may be the most effective. Recently, it has been reported that the enzymatic hydrolysis of the seed cell wall and the rupturing of polysaccharide-protein colloid improve oil recovery by decreasing emulsion formation (Shende and Sidhu, 2014). However, the combination of fungal cellulase and bacterial protease or bovine pancreatic protease in the extraction process resulted in a more pronounced increase in the relative oil yield (62.38, $51.94 \%$, respectively), compared to those obtained by the individual enzymes (Table 2). Previouly, Huang (1996) reported that lipid bodies are surrounded by a half unit phospholipid monolayer membrane and an oleosin protein, and that proteases may be effective for oil recovery. This suggestion could account for the synergistic effect of the combination of fungal cellulase and proteases on oil extraction.

Studying the physical and chemical characteristics of a vegetable oil is the key step in evaluating its quality. The enzymatic extraction method was found to modify some of the physical and chemical parameters of the oil. Compared to hexane extraction, the color index of the oil was significantly reduced by extraction using the different enzymes, either individually or in combination, with the exception of cellulase (Table 3). It has been reported that hexane enhances the solubility of the pigments in the oil leading to an increase in its color index, which makes further oil processing like degumming, refining and bleaching necessary, by which the pigments and other undesirable substances are removed (Latif and Anwar, 2009). On the contrary, the enzymatic extraction method results in a poor solubility of the coloring pigments, which is reflected by the low color index of the enzyme extracted-oil samples. It is well known that vegetable oil with low color index is more acceptable and suitable for edible and industrial purposes (Anwar et al., 2005). The refractive index of a vegetable oil is an optical measurment that is related to the oil structure and is used to monitor any change that might take place in the oil structure, for example, a partially oxidized or polymerized oil will have a higher refractive index than the fresh oil (Formo et al., 1979). The refractive index of the different oil samples was not significantly changed compared to hexane extraction (Table 3).

The acid values for the corn germ oil extracted by the different enzymes were lower than that of hexane extraction, which could be attributed to the minimal lipolytic activity of the enzymatic extraction under the implemented conditions. It has been reported that in hexane extraction, an accelerated temperature is used, which increases the lipolytic activity and results in an increase in the acid value of the extracted oil (Moreau et al., 2004; Latif and Anwar, 2009). The iodine value measures the degree of unsaturation in the oil, and the saponification value is an index of the average molecular mass of the fatty acids in the oil sample (Formo et al., 1979). Our results showed that the iodine and saponification values for the different enzyme-extracted oil samples were not significantly changed compared to hexane extraction, which indicates that the enzymatic extraction did not affect the overall oil composition. These findings are also supported by the results of the fatty acid composition. The analysis of fatty acids in the oil samples extracted either by hexane or enzymatic means showed mild variations, indicating that enzymatic extraction did not affect the fatty acids composition of the extracted oil. The total unsaturated fatty acids represent the major component of corn germ oil (85.7-87.23\%), while the percentage of total saturated fatty acids ranged from 12.77 to $14.31 \%$ (Table 4). Furthermore, linoleic acid (C18:2) (w-6) is the prevalent essential polyunsaturated fatty acid (51.64-53.11\%), followed by the monounsaturated oleic acid (w-9) (32.24-33.27\%), while the essential polyunsaturated $\alpha$-linolenic acid $(\mathrm{C} 18: 3)(\mathrm{w}-3)$ is present in the smallest amount $(0.95-$ $1.11 \%)$. Linoleic acid can be converted to longer omega-6 fatty acids, such as arachidonic acid, which are used to produce eicosanoids, which are more pro-inflammatory (Calder, 2013). Pro-inflammatory eicosanoids are important chemicals in the immune system, however when too many of them are produced, they can cause an increase in inflammatory diseases (Calder, 2015). Omega-9 fatty acids are important for reducing plasma triglycerides, VLDL and cholesterol in diabetic patients (Brehm et al., 2009). They also improve insulin sensitivity and decreased inflammation (Finucane et al., 2015). Parallel results were previously reported, where corn 
germ oil contained $86 \%$ unsaturated fatty acids and $13 \%$ saturated fatty acids, which makes it a healthy fat for the heart (Shende and Sidhu, 2014). In addition, Latif and Anwar (2009 and 2011) reported no significant variations in the iodine value, refractive index, or fatty acids composition of the enzyme extracted-vegetable oils.

Antioxidants are used as lipid stabilizers in the food industry. Tocopherols are important natural antioxidant compounds in oils. It is worth noting that the oil sample extracted by the newly used bovine pancreatic protease contained the highest tocopherol concentration, compared to hexane and other enzymes (Table 5). Latif and Anwar (2009) reported that enzyme treatment offers an enhanced release of minor components (polyphenols, tocopherols, volatiles, carotenes, xanthophylls and chlorophylls) into the oil phase, and consequently improves the analytical parameters related to flavor and shelflife. The considerable concentration of tocopherols present in the oil samples extracted by the different enzymes caused a reduction in hydroperoxide formation, compared to hexane extraction

The radical scavenging activity of oils may be influenced by the radical system and other testing conditions, thus for estimating the radical scavenging power of antioxidants, a stable radical, such as DPPH is used (Yu et al., 2002). Corn germ oil produced by combining cellulase and bovine pancreatic protease showed the highest DPPH scavenging activity amongst all the tested oil samples despite its lowest tocopherol content, which might be due to the presence of other phenolic compounds. Tirzitis and Bartosz (2010) have emphasized that there is a great difference between "antiradical" and "antioxidant" activity and that they do not necessarily coincide. According to Burlakova and coworkers (1975), the antiradical activity characterizes the ability of compounds to react with free radicals (in a single free radical reaction), but the antioxidant activity represents the ability to inhibit the process of oxidation (which in the case of lipids, involves a set of different reactions).

The oxidative stability of oils is the resistance to oxidation during processing and storage. It is an important indicator to determine palatability, oil quality and shelf life. The oxidation of oil destroys essential fatty acids and produces toxic compounds and oxidized polymers. The oxidation of oil is influenced by the fatty acids composition, oil processing, energy of heat or light, concentration and type of oxygen, free fatty acids, pigments and antioxidants (Choe and Min, 2006).

The peroxide value is commonly used to estimate the level of oxidative deterioration in oils. Codex Alimentarius Commission (1982) stipulated a permitted maximum peroxide level of not more than 10 $\mathrm{mEq} / \mathrm{kg}$ oil (Anjum et al., 2006). The peroxide values of all the oil samples were below the acceptable level, however, lower peroxide values were observed in the oil samples extracted by cellulase and bovine protease enzymes individually. This might be due to the mild conditions used in enzyme extraction, compared to hexane extraction, where an accelerated temperature may be used.

The Rancimat method is a powerful and fast technique for estimating the oxidative stability of oils (Kowalski et al., 2004). The induction period (accelerated oxidation test) of the corn oil samples extracted by the different enzymes, individually or in combination, was significantly lower than that of crude hexane-extracted oil. Lamas et al., (2014) stated that the oxidative stability of an oil is affected by its content of minor components, with antioxidant or pro-oxidant characteristics. Phospholipids are one of these minor components which have strong antioxidant effects and naturally transfer to the oil during extraction. They attributed the significant decrease in the induction period after enzymatic degumming compared to that of the crude oil due to the great reduction in phospholipid content after degumming. Bocevska et al., (1993) compared among hexane extracted, degummed and aqueous enzymatic extracted corn oils. The authors reported that the oil obtained by enzymatic extraction is similar to the degummed oil with low phosphatide content, compared to the hexane extracted oil, which suggests the possibility of employing physical refining. Another point of view suggested that the decrease in the phospholipid content after aqueous enzymatic extraction was probably not due to the enzyme treatment, but resulted from the washing effect of the water (Mehanni et al., 2017). So the significant decrease in the induction period observed in our study after the aqueous enzymatic extraction might be due to the reduction in phospholipid content compared to hexane extraction where phospholipids are dissolved and extracted along with the oil. This led to the notion that the prolonged induction period of oil extracted by hexane might be attributed due to its phosphatide and tocopherol contents as well as the presence of other bioactive components like polyphenols. Mehanni et al., (2017) suggested that the physical refining that may be employed during aqueous enzymatic extraction is considered to be one of the advantages of enzymatic extraction as the overall cost of the refining process is reduced and there is no need for degumming.

\section{CONCLUSIONS}

Enzymatic aqueous extraction of corn germ oil is considered an alternative eco-friendly method to produce valuable products without loss of quality at moderate conditions with an advantage of enzyme specificity. Applying bovine pancreatic protease in corn germ oil extraction produced a maximum oil yield $(5.97 \mathrm{~g} \%)$ at $0.1 \%$ enzyme concentration, $15 \%$ 
corn germ concentration, $\mathrm{pH} 7.5$ and incubation time of $60 \mathrm{~min}$. The combination of cellulase and bacterial or animal protease in the extraction process produced higher oil yield than individual application. The quality of oil extracted by the enzymatic aqueous method is better than that extracted by the traditional hexane method based on the lower color index and acid value. Moreover, lower peroxide values were reported for the oil samples extracted by cellulase and bovine protease individually and higher radical scavenging activity was recorded for the oil sample produced by combining cellulase with animal protease. Despite these advantages, the high cost of the enzymes and the difficulty to scale up for large volumes are considered limitations of the aqueous enzymatic extraction technique. Thus, using immobilized enzymes can prolong enzyme life and reduce the costs.

\section{ACKNOWLEDGEMENT}

The authors gratefully acknowledge Prof. Dr. Antoni Szumny, Acting Head of The Department of Chemistry, Wrocław University of Environmental and Life Sciences, Poland, for providing laboratory facilities.

\section{Conflict of interest}

The authors declare that there are no conflicts of interest.

\section{REFERENCES}

Anjum F, Anwar F, Jamil A, Iqbal M. 2006. Microwave roasting effects on the physico-chemical composition and oxidative stability of sunflower seed oil. J. Am. Oil Chem. Soc. 83, 777-784. https://doi.org/10.1007/s11746-006-5014-1

Anwar F, Ashraf M, Bhanger MI. 2005. Interprovenance variation in the composition of Moringa oleifera oilseeds from Pakistan. J. Am. Oil Chem. Soc. 82, 45-51. https://doi. org/10.1007/s11746-005-1041-1

AOAC, 2005. Official Methods of Analysis of the Association of Official Analytical Chemists. $18^{\text {th }}$ Ed., Gaithersburg, USA.

AOCS, 2005 in: Firestone D. (Edn.), Official Methods and Recommended Practices of the American Oil Chemists' Society, AOCS Press, Champaign, IL. Methods Cd 1-25, Cd 3a-63, Cd 3-25 and Cd 8-53.

Balvardi M, Rezaei K, Mendiola JA, Ibáñez E. 2015. Optimization of the aqueous enzymatic extraction of oil from Iranian wild almond. J. Am. Oil Chem. Soc. 92, 985992. https://doi.org/10.1007/s11746-015-2671-y

Barminas JT, James MK, Abubakar UM. 1999. Chemical composition of seeds and oil of Xylopia Aethiopica grown in Nigeria. Plant Food Hum. Nutr. 53, 193-198.

Bender DA. 2009. A dictionary of food and nutrition. $3^{\text {rd }}$ edition, Oxford university press.

Blois MS. 1958. Antioxidant determinations by the use of a stable free radical. Nature 181, 1199-1200. https://doi. org/10.1038/1811199a0

Bocevska M, Karlović D, Turkulov J, Pericin D. 1993. Quality of corn germ oil obtained by aqueous enzymatic extraction. J. Am. Oil Chem. Soc. 70, 1273-1277. https://doi. org/10.1007/BF02564241

Brehm BJ, Lattin BL, Summer SS, Boback JA, Gilchrist GM, Jandacek RJ, D'alessio DA. 2009. One-year comparison of a high-monounsaturated fat diet with a high-carbohydrate diet in type 2 diabetes. Diabetes Care 32, 215-220. https:// doi.org/10.2337/dc08-0687

Burlakova EB, Alesenko AV, Molochkina EM, Palmina NP, Khrapova NG. 1975. Bioantioxidants in radiation damage and malignant growth. Moscow: Nauka (in Russian).

Calder PC. 2013. Omega-3 polyunsaturated fatty acids and inflammatory processes: nutrition or pharmacology?. Br. J. Clin. Pharmacol. 75, 645-662. https://doi. org/10.1111/j.1365-2125.2012.04374.x

Calder PC. 2015. Marine omega-3 fatty acids and inflammatory processes: effects, mechanisms and clinical relevance. Biochim. Biophys. Acta 1851, 469-484. https://doi. org/10.1016/j.bbalip.2014.08.010

Choe E, Min DB. 2006. Mechanisms and factors for edible oil oxidation. Comprehensive reviews in food science and food safety 5, 169-186. https://doi. org/10.1111/j.1541-4337.2006.00009.x

Finucane OM, Lyons CL, Murphy AM, Reynolds CM, Klinger R, Healy NP, Cooke AA, Coll RC, McAllan L, Nilaweera KN, O'Reilly ME. 2015. Monounsaturated fatty acidenriched high-fat diets impede adipose NLRP3 inflammasome-mediated IL-1 $\beta$ secretion and insulin resistance despite obesity. Diabetes 64, 2116-2128. https://doi. org/10.2337/db14-1098

Formo MW, Jungermann E, Norris FA, Sonntag NOV. 1979. Baily's Oil and Fat Products. 4th edn. by D.Swern, Interscience Publishers, New York, USA.

Huang AH. 1996. Oleosins and oil bodies in seeds and other organs. Plant Physiology 110, 1055-1061. https://doi. org/10.1104/pp.110.4.1055

Johnston DB, McAloon AJ, Moreau RA, Hicks KB, Singh V. 2005. Composition and economic comparison of germ fractions from modified corn processing technologies. $J$. Am. Oil Chem. Soc. 82, 603-608. https://doi.org/10.1007/ s11746-005-1116-Z

Kowalski B, Ratusz K, Kowalska D, Bekas W. 2004. Determination of the oxidative stability of vegetable oils by differential scanning calorimetry and Rancimat measurements. Eur. J. Lipid Sci. Technol. 106, 165-169. https:// doi.org/10.1002/ejlt.200300915

Lamas DL, Crapiste GH, Constenla DT. 2014. Changes in quality and composition of sunflower oil during enzymatic degumming process. LWT - Food Sci. Technol. 58, 71-76. https://doi.org/10.1016/j.lwt.2014.02.024

Latif S, Anwar F. 2009. Effect of aqueous enzymatic processes on sunflower oil quality. J. Am. Oil Chem. Soc. 86, 393400. https://doi.org/10.1007/s11746-009-1357-8

Latif S, Anwar F. 2011. Aqueous enzymatic sesame oil and protein extraction. Food chem. 125, 679-684. https://doi. org/10.1016/j.foodchem.2010.09.064

Mehanni AES, El-Reffaei WHM, Melo A, Casal S, Ferreira IM. 2017. Enzymatic Extraction of Oil from Balanites Aegyptiaca (Desert Date) Kernel and Comparison with Solvent Extracted Oil. J. Food Biochem. 41. https://doi. org/10.1111/jfbc. 12270

Mojtaba A, Fardin K. 2013. Optimization of enzymatic extraction of oil from Pistacia Khinjuk seeds by using central composite design. Food Sci. Technol. ${ }^{\circ}$ 1, 37-43.

Moral PS, Méndez MVR. 2006. Production of pomace olive oil. Grasas Aceites 57, 47-55.

Moreau RA, Dickey LC, Johnston DB, Hicks KB. 2009. A process for the aqueous enzymatic extraction of corn oil from dry milled corn germ and enzymatic wet milled corn germ (E-Germ). J. Am. Oil Chem. Soc. 86, 469-474. https://doi. org/10.1007/s11746-009-1363-X

Moreau RA, Johnston DB, Dickey LC, Parris N, Hicks KB. 2007. Aqueous enzymatic oil extraction: a "green" bioprocess to obtain oil from corn germ and other oil-rich plant materials, in: Eggleston G, Vercellotti JR (eds). ${ }^{\circ}$ The industrial application of enzymes on carbohydrate based materials. American Oil Chemists' Society Press, Champaign, 101-120. https://doi.org/10.1021/bk-2007-0972.ch008

Moreau RA, Johnston DB, Powell MJ, Hicks KB. 2004. A comparison of commercial enzymes for the aqueous enzymatic extraction of corn oil from corn germ. J. Am. 
Physicochemical characteristics and oxidative stability of Egyptian corn germ oil produced by aqueous enzymatic extraction $\bullet 13$

Oil Chem. Soc. 81, 1071-1075. https://doi.org/10.1007/ s11746-004-1023-3

Pearson D. 1976. Chemical Analysis of Foods. $7^{\text {th }}$ Edn., Church Hill Livingstone, London, UK, 72-73,138-143, 488-496.

Pons WA, Kuck JC, Frampton VL. 1960. Color index for cottonseed oils. J. Am. Oil Chem. Soc. 37, 671-673. https://doi. org/10.1007/BF02632095

Rao MB, Tanksale AM, Ghatge MS, Deshpande VV. 1998. Molecular and biotechnological aspects of microbial proteases. Microbiol. Mol. Biol. Rev. 62, 597-635.

Shende D, Sidhu EK. 2014. Methods Used for Extraction of Maize (Zea Mays L.) Germ Oil-A Review. Ind. J. Sci. Res. and Tech. 2, 48-54.

Tirzitis G, Bartosz G. 2010. Determination of antiradical and antioxidant activity: basic principles and new insights. Acta Biochimica Polonica 57, 139-142.
Turan S, Topcu A, Karabulut I, Vural H, Hayaloglu AA. 2007. Fatty acid, triacylglycerol, phytosterol, and tocopherol variations in kernel oil of Malatya apricots from Turkey. J. Agric. Food Chem. 55, 10787-10794. https://doi. org/10.1021/jf071801p

Wirasnita R, Hadibarata T Novelina YM, Yusoff ARM, Yusop Z. 2013. A modified methylation method to determine fatty acid content by gas chromatography. Bull. Korean Chem. Soc. 34, 3239-3242. https://doi.org/10.5012/ bkcs.2013.34.11.3239

Xie M, Dunford NT, Goad C. 2011. Enzymatic extraction of wheat germ oil. J. Am. Oil Chem. Soc. 88, 2015-2021. https://doi.org/10.1007/s11746-011-1861-5

Yu L, Haley S, Perret J, Harris M, Wilson J, Qian M. 2002. Free radical scavenging properties of wheat extracts. $J$. Agric. Food Chem. 50, 1619-1624. https://doi.org/10.1021/ jf010964p 